\title{
Impact of actions of food and nutrition education program in a population of adolescents
}

\author{
Impacto das ações de um programa de educação \\ alimentar e nutricional em uma \\ população de adolescentes
}

Juliana Garcia BALDASSO ${ }^{1}$

Andréa Polo GALANTE ${ }^{1}$

Aline DE PIANO GANEN ${ }^{1}$

A B S T R A C T

\section{Objective}

To evaluate changes in food intake after adolescents attended a food and nutrition education program at a non-profit institution.

\section{Methods}

Fifty-four adolescents aged 16 to 19 years, of low socioeconomic level, enrolled in an non-governmental organization in São Paulo, underwent a nutritional intervention of six months consisting of six meetings with dieticians, as well as strategic communication and relationship actions. Body weight, height, body mass index, questionnaire on knowledge on nutrition and feeding practices, 24-hour recall, and diet quality assessment using the Diet Quality Index associated with the Digital Food Guide were collected at baseline and after the intervention. Dietary pattern improvement was defined as an increase of at least 5 points in Diet Quality Index associated with the Digital Food Guide.

\section{Results}

Understanding of food labels increased, and the dietary patterns on weekdays and weekends improved by 33 and $37 \%$, respectively. The intake of legumes, milk, dairy products, fruits, and vegetables increased (adequacy components). However, intakes of nuts and whole grains were low, and intake of moderation components was high.

\section{Conclusion}

The program improved the dietary patterns of adolescents, making it a viable and inexpensive method to prevent disease and improve health and quality of life. In addition, the Diet Quality Index associated with the

\footnotetext{
1 Centro Universitário São Camilo, Mestrado Profissional em Nutrição: do nascimento à adolescência. R. Raul Pompéia, 144, Pompéia, 05025-010, São Paulo, SP, Brasil. Correspondência para/Correspondence to: A DE PIANO GANEN. E-mail: <aline.depiano@gmail.com>.
} 
Digital Food Guide has proven to be a good nutritional tool for assessing changes in food intake and for guiding future counseling and nutritional intervention actions for this population.

Keywords: Adolescent. Food and nutrition education. Food consumption.

\section{RES U M O}

\section{Objetivo}

Avaliar as mudanças no consumo alimentar após aplicação de um programa de educação alimentar e nutricional com adolescentes de uma instituição do terceiro setor.

\section{Métodos}

Cinquenta e quatro adolescentes com idade entre 16 e 19 anos, de baixo nível socioeconômico, matriculados em uma organização não governamental de São Paulo foram submetidos à intervenção nutricional de seis meses, que consistiu de seis encontros com nutricionistas e ações estratégicas de comunicação e relacionamento. Massa corporal, estatura, índice de massa corporal, questionário sobre conhecimento de nutrição e práticas alimentares, recordatório de 24 horas e qualidade da dieta pelo Índice de Qualidade da Dieta associado ao Guia Alimentar Digital foram avaliados no início e no final da intervenção. Considerou-se como melhora no padrão alimentar o aumento de no mínimo cinco pontos no Índice de Qualidade da Dieta associado ao Guia Alimentar Digital.

\section{Resultados}

Observaram-se maior conhecimento sobre as informações disponibilizadas no rótulo dos alimentos e melhora no padrão da dieta de 33\% dos alunos durante a semana e 37\% aos finais de semana. Verificou-se aumento na ingestão de alimentos dos grupos leguminosas, leites e derivados, frutas e hortaliças (componentes de adequação). Entretanto, houve baixa ingestão de oleaginosas e cereais integrais e elevada ingestão dos componentes de moderação.

\section{Conclusão}

O programa promoveu melhoras no padrão alimentar dos adolescentes, tornando-se um método viável, de baixo custo e aplicável para a prevenção de doenças e melhoria da qualidade de vida e da saúde. Além disso, o Índice de Qualidade da Dieta associado ao Guia Alimentar Digital mostrou ser uma boa ferramenta nutricional para avaliar mudanças no consumo alimentar e nortear futuras orientações e ações de intervenção nutricional nessa população.

Palavras-chave: Adolescente. Educação alimentar e nutricional. Consumo de alimentos.

\section{INTRODUCTION}

Food and nutrition are basic requirements for health promotion and protection, enabling full attainment of human growth and development with quality of life and citizenship. Nutritional risks of different magnitudes and categories permeate the entire human life cycle, assuming various epidemiological configurations and function of each population's health/disease process ${ }^{1}$.

From the nutritional point of view, adolescents are considered vulnerable individuals because of their current dietary pattern, which is typically low in micronutrients and high in sugars and fats. Currently, adolescent obesity is a universal disease with a growing global prevalence, assuming the epidemiological nature of a public health problem. The promotion of a healthy diet is one of the main public health strategies for facing these food and nutrition problems in the current context because they consist of a strategy capable of preventing nutritional deficiencies and of reducing the incidence of overweight and other Chronic Non-Communicable Diseases (NCD), such as obesity, diabetes, hypertension, and cancer ${ }^{2}$.

Regarding adolescents, the dietician's technical and scientific knowledge should be shared at the same rhythm as the adolescent's knowledge and life experiences are problematized since changing food habits requires more 
understanding than food prescription or forbiddance, resulting in desired attitudes and behaviors. Providing these skills to adolescents at school encourages them and increases their knowledge about healthy eating ${ }^{3}$.

Education institutions, including philanthropic and aid-oriented entities and institutions, have been one of the preferred spaces for public food and nutrition policies that promote a healthy diet because they are recognized as one of the main locations for the formation of food habits and choices $^{3,4}$. Large-scale health education programs should be provided in these environments, including food and nutrition education programs that focus on the development of actions that improve students' health and nutritional status. Such programs should be incorporated in the teaching plan, constructing knowledge in a crosssectional manner, using active, fun, and interactive processes that promote changes in food attitudes and practices, guaranteeing the sustainability of the actions inside and outside the classroom ${ }^{5}$.

The development of nutrition education programs for youth attending non-profit institutions is essential for increasing their ability to understand proper food practices, encouraging these individuals to become active in a social transformation process by spreading these healthy food habits and contributing to the establishment of a society with better future perspectives.

Despite the incentive given to food and nutrition education in education institutions, there are very few reports in the literature about the implementation of successful actions in most Brazilian municipalities. There is also a scarcity of similar studies involving adolescents, making it necessary to reassess the usual nutritional interventions made on this group. The focus should cover knowledge of the food behavior of an individual and his social group, and the collective construction of the adopted strategies. Interventions based on the target population's concepts, requirements, and beliefs are more likely to promote healthy food practices effectively ${ }^{6}$.

In face of the aspects discussed above, the search for successful intervention models is clearly a challenge for dieticians. Analysis of the effects of food and nutrition education interventions on this population allows the identification of their strengths and aspects that need more work, allowing professionals involved in their provision to improve them in a way that encourages participants to consider changing their food habits and to realize the importance of doing so, associating better food habits with better health. Thus, the objective of the present study was to assess changes in the dietary pattern of adolescents attending a non-profit institution located in the municipality of São Paulo after they were submitted to the actions of a food and nutrition education program.

\section{METHODS}

This is a non-controlled intervention study with assessments made before and after a 6-month food and nutrition education program. The study was developed at a Non-Governmental Organization (NGO) located in the city of São Paulo. The NGO aims to promote the professional, sociocultural, and personal development of socially and economically vulnerable youth using audiovisual aids. Youth of low socioeconomic level aged 16 to 21 years $(18.0 \pm 0.54)$ attend the institution full time on an annual basis, from Monday to Friday. The institution offers three meals a day (breakfast, lunch, and afternoon snack). The study population consisted of students enrolled in the institution from August 2013 to July 2014. In face of the challenge of nonprofit organizations, the scarcity of studies with adolescents, and the important mission of an NGO that works with vulnerable youth, which directly interferes on youth's dietary patterns, led the main researcher to choose this population over the many projects she has developed. Therefore, this is a convenience sample. 
The study included male and female adolescents aged 16 to 19 years enrolled in a nonprofit institution. None of the participants were pregnant or had special needs. Their parents or guardians authorized their participation in the study. Students who participated in less than $75 \%$ of the actions of the food and nutrition education program were excluded from the study. The Research Ethics Committee of Centro Universitário São Camilo approved the study without restrictions under Protocol $n^{\circ} 446.036$.

The educational actions were provided for six months at the institution. The food and nutrition education program included activities, such as lectures, nutritional counseling, cooking workshops, and group dynamics, distributed throughout six meetings with the nutrition team, in addition to communication and relationship actions and strategies using an announcement board for six months to support the program and strengthen the bond with the students.

The students' body weight and height were measured as suggested by Sistema de Vigilância Alimentar Nutricional (Sisvan) ${ }^{7}$. The body mass index of the adolescents was calculated, and their nutritional status was classified as recommended by the World Health Organization $(\mathrm{WHO})^{8}$.

A specific questionnaire assessed the adolescents' knowledge on nutrition and food practices related to the main themes covered by the educational actions. The data were tabulated and analyzed statistically to investigate possible associations between the variables.

Food intake was assessed by a 24-Hour Recall (24HR). Food records of two non-consecutive days, namely a weekday and a weekend day, of each adolescent were also collected.

The data collected by the $24 \mathrm{HR}$ were processed by the software MSAccess ${ }^{\circledR}$ (Microsoft, São Paulo, Brazil) version 11 and converted by the system into food groups and corresponding servings according to the criteria provided by the "Índice de Qualidade da Dieta associado ao Guia
Alimentar Digital" (IQD-GAD, Diet Quality Index associated with the Digital Food Guide), created by Caivano \& Domene ${ }^{9}$. The energy content was given by the "Tabela Brasileira de Composição de alimentos" (Taco, Brazilian Food Composition Table $)^{10}$ and the nutrient database of the United States Department of Agriculture (USDA) ${ }^{11}$.

The Diet Quality Index associated with the Digital Food Guide assesses food choices, classifying food groups into two categories: moderation components, consisting of food groups that contain hazardous compounds when overeaten; and adequacy components, consisting of food groups that contain nutrients and bioactive compounds that provide essential nutrients. The IQD-GAD has a maximum score of 100 points. The scores are classified as follows: 0-49 points: poor quality diet; $50-80$ points: intermediate quality diet; and 81-100 points: high quality diet.

According to the intervention model, an increase of at least five points between the IQD-GAD before and after the intervention indicated that the intervention improved the adolescents' dietary pattern. Although the IQD-GAD ${ }^{9}$ was developed for adults, we chose to use it because it is recent, validated, geared towards the Brazilian dietary habits, based on the nutritional requirements established by the Institute of Medicine $(\mathrm{IOM})^{12,13}$, encourages a dietary pattern that aims to prevent chronic diseases, and has reliability similar to that of foreign indices. The macro- and micronutrient (calcium, magnesium, iron, sodium, zinc, and vitamin A) contents of this index's reference diet are close to the nutritional quotas established by the Dietary Reference Intakes for the sex and age of the study adolescents.

The results were analyzed descriptively, which included measures of central tendency (mean and median), dispersion (standard deviation, minimum, and maximum), and frequency (\%). The Kolmogorov-Smirnov test investigated whether the variables had normal distribution. The Pearson's Chi-square test compared the body 
mass indices of the adolescents before and after the intervention. The binomial test analyzed whether the intervention improved the adolescents' dietary patterns by classifying the patterns as recommended by the IQD-GAD. The number of servings of each dietary component before and after the intervention was compared by the Student's $t$ test for parametric variables, and by the Wilcoxon test for non-parametric variables. The statistical analyses were performed by the software Sciences Statistical Package for the Social Sciences (SPSS Inc., Chicago, Illinois, United States) version 18 for Windows (Microsoft Corporation, Redmond, Washington, United States) and the significance level was set at $5 \%(p<0.05)$.

\section{RE S U L T S}

Of the 135 individuals enrolled in the institution, $66.7 \%$ were adolescents. Of these, $96.7 \%$ met the inclusion criteria; of these, $37.9 \%$ were excluded because their participation in actions of the food and nutrition education program was below $75.0 \%$. Hence, the study sample consisted of 54 students, most of which were females aged 17 to 18 years with complete high school education. Table 1 shows the anthropometric characteristics of the study participants.

Anthropometric assessment showed a prevalence of overweight and obesity of $24.2 \%$ before and after the intervention. However, the Body Mass Index (BMI) of 5.6\% of the participants decreased, migrating from a status of obesity to overweight. Although the BMl of some students remained inappropriate, the nutritional intervention improved their nutritional profile significantly (Table 1).

The adolescents' intakes of salt, sugar, and milk before and after the food and nutrition education program were investigated. After the intervention, 9.3 and $7.4 \%$ of the students no longer added salt to food or sugar to juice, respectively. The intervention increased the percentage of students who consumed milk from 70.4 to $90.7 \%$, and $6.4 \%$ of the students substituted whole milk by either semi-skimmed $(4.3 \%)$ or skimmed $(2.1 \%)$ milk (data not shown).

Nutrition knowledge and understanding of food labels clearly increased after the intervention: $50 \%$ of the students started reading food labels, and $63 \%$ began to understand the information therein.

After the intervention, 33\% of the sample had improved their diet during the week (from Monday to Friday), and $37 \%$ had improved their diet during the weekend by at least five points in the IQD-GAD.

Table 2 shows the change in dietary patterns according to IQD-GAD classification. Although not statistically significant, the percentage of students with low quality diet decreased by $16.6 \%$ during the week and by $11.1 \%$ during the weekend. All of these cases went from a poor-quality diet to an intermediatequality diet, increasing the percentage of students with an intermediate-quality diet on weekdays and weekends. The percentages of students with

Table 1. Anthropometric characteristics of the students who participated in the program before and after the intervention. São Paulo (SP), Brazil, 2015.

\begin{tabular}{lccccc}
\hline \multirow{2}{*}{ Body mass index classification } & \multicolumn{2}{c}{ Pre-intervention } & & \multicolumn{2}{c}{ Post-intervention } \\
\cline { 2 - 3 } \cline { 5 - 6 } & $\mathrm{n}$ & $\%$ & $\mathrm{n}$ & 1 & 1.9 \\
\hline Underweight & 0 & 0.0 & 40 & 74.1 \\
Normal weight & 41 & 75.9 & 6 & 11.1 \\
Overweight & 3 & 5.6 & 7 & 13.0 \\
Obese & 10 & 18.5 & 54 & 100.0 \\
\hline Total & 54 & 100.0 &
\end{tabular}

Note: $p=0.00$ according to Pearson's Chi-square test. 
a good-quality diet on weekdays and weekends, before and after the intervention, did not change. None of the students had a good-quality diet on weekends.

Tables 3 and 4 contain data on the number of servings consumed of each food component before and after the intervention. Intake of legumes, milk, dairy products, fruits, and vegetables increased significantly during the week and weekend, meeting the daily recommendations for legumes, milk, and dairy products. The intake of poultry, seafood, and eggs increased significantly on weekends, and the intake of vegetable oils during these days decreased but not significantly.

The intervention did not change the intake of nuts and whole grains, which remained inadequate after the intervention. Likewise, the intervention had no impact on most food groups

Table 2. Classification of diet quality before and after the intervention. São Paulo (SP), Brazil, 2015.

\begin{tabular}{|c|c|c|c|c|c|}
\hline \multirow{3}{*}{ Variables } & \multicolumn{5}{|c|}{ Diet Quality Index associated with the Digital Food Guide } \\
\hline & \multicolumn{2}{|c|}{ Pre-intervention } & \multicolumn{2}{|c|}{ Pre-intervention } & \multirow{2}{*}{$p^{*}$} \\
\hline & $\mathrm{n}$ & $\%$ & $\mathrm{n}$ & $\%$ & \\
\hline \multicolumn{6}{|l|}{ Weekday } \\
\hline Low quality & 51 & 94.4 & 42 & 77.8 & 0.10 \\
\hline Intermediate quality & 2 & 3.7 & 11 & 20.4 & \\
\hline Good quality & 1 & 1.9 & 1 & 1.9 & \\
\hline Total & 54 & 100.0 & 54 & 100.0 & \\
\hline \multicolumn{6}{|l|}{ Weekend day } \\
\hline Low quality & 37 & 68.5 & 31 & 57.4 & 0.29 \\
\hline Intermediate quality & 17 & 31.5 & 23 & 42.6 & \\
\hline Good quality & 0 & 0.0 & 0 & 0.0 & \\
\hline Total & 54 & 100.0 & 54 & 100.0 & \\
\hline
\end{tabular}

Note: *Binominal test.

Table 3. Number of servings consumed of each food component on weekdays before and after the intervention. São Paulo (SP), Brazil, 2015

\begin{tabular}{|c|c|c|c|c|c|c|}
\hline \multirow{2}{*}{ Components } & \multirow{2}{*}{$\begin{array}{c}\text { Reference } \\
\text { range (serving) }\end{array}$} & \multicolumn{2}{|c|}{ Pre-intervention } & \multicolumn{2}{|c|}{ Post-intervention } & \multirow{2}{*}{$p^{* *}$} \\
\hline & & Median & Min - Max & Median & Min - Max & \\
\hline \multicolumn{7}{|l|}{ Moderation components } \\
\hline Sugars and sweets & 0.0 to 1.0 & 6.67 & $0.00-28.59$ & 6.90 & $0.00-27.88$ & 0.47 \\
\hline Refined grains and breads & 0.0 to 1.0 & 5.44 & $0.00-21.03$ & 6.26 & $0.00-21.65$ & 0.11 \\
\hline Beef and pork & 0.0 to 1.0 & 2.54 & $0.00-11.02$ & 2.34 & $0.00-11.86$ & 0.23 \\
\hline Animal fat & 0.0 to 1.0 & 0.00 & $0.00-9.44$ & 0.00 & $0.00-7.57$ & 0.84 \\
\hline \multicolumn{7}{|l|}{ Adequacy components } \\
\hline Poultry, seafood, and eggs & 0.0 to 2.0 & 0.81 & $0.00-8.61$ & 0.47 & $0.00-8.61$ & 0.84 \\
\hline Whole grains and breads* & 4.0 to 6.0 & 0.00 & $0.00-2.76$ & 0.00 & $0.00-5.88$ & 0.40 \\
\hline Fruits & 3.0 to 5.0 & 0.00 & $0.00-3.95$ & 2.00 & $0.00-4.28$ & 0.05 \\
\hline Vegetables & 4.0 to 5.0 & 1.08 & $0.00-6.75$ & 3.23 & $0.00-22.78$ & 0.00 \\
\hline Legumes & 2.0 to 3.0 & 0.93 & $0.00-7.66$ & 2.55 & $0.00-5.10$ & 0.00 \\
\hline Milk and dairy products & 1.5 to 2.5 & 0.55 & $0.00-7.45$ & 1.91 & $0.00-19.90$ & 0.00 \\
\hline Nuts & 0.5 to 1.5 & 0.00 & $0.00-4.04$ & 0.00 & $0.00-7.78$ & 0.65 \\
\hline Vegetable oils & 2.0 to 3.0 & 2.02 & $0.00-11.61$ & 2.20 & $0.00-13.49$ & 0.07 \\
\hline
\end{tabular}

Note: "Whole grains and bread, tubers, and roots; ${ }^{* *}$ Tests for analyzing servings before $\mathrm{x}$ after intervention: Wilcoxon for nonparametric variables and Student's $t$ test for parametric variables.

Min: Minimum; Max: Maximum. 
Table 4. Number of servings consumed of each food component on weekends before and after the intervention. São Paulo (SP), Brazil, 2015.

\begin{tabular}{|c|c|c|c|c|c|c|}
\hline \multirow{2}{*}{ Components } & \multirow{2}{*}{$\begin{array}{c}\text { Reference } \\
\text { range (serving) }\end{array}$} & \multicolumn{2}{|c|}{ Pre-intervention } & \multicolumn{2}{|c|}{ Post-intervention } & \multirow{2}{*}{$p^{* *}$} \\
\hline & & Median & Min - Max & Median & Min - Max & \\
\hline \multicolumn{7}{|l|}{ Moderation components } \\
\hline Sugars and sweets & 0.0 to 1.0 & 3.52 & $0.00-29.12$ & 3.29 & $0.00-28.88$ & 0.97 \\
\hline Refined grains and breads & 0.0 to 1.0 & 4.45 & $1.49-15.04$ & 5.18 & $1.17-15.27$ & 0.15 \\
\hline Beef and pork & 0.0 to 1.0 & 1.84 & $0.00-9.75$ & 1.60 & $0.00-14.75$ & 0.26 \\
\hline Animal fat & 0.0 to 1.0 & 0.00 & $0.00-4.36$ & 0.00 & $0.00-7.50$ & 0.96 \\
\hline \multicolumn{7}{|l|}{ Adequacy components } \\
\hline Poultry, seafood, and eggs & 0.0 to 2.0 & 0.00 & $0.00-9.42$ & 0.62 & $0.00-12.84$ & 0.02 \\
\hline Whole grains and breads ${ }^{*}$ & 4.0 to 6.0 & 0.00 & $0.00-2.17$ & 0.00 & $0.00-11.06$ & 0.13 \\
\hline Fruits & 3.0 to 5.0 & 0.54 & $0.00-3.80$ & 1.50 & $0.00-5.44$ & 0.03 \\
\hline Vegetables & 4.0 to 5.0 & 0.59 & $0.04-6.92$ & 2.05 & $0.00-16.62$ & 0.05 \\
\hline Legumes & 2.0 to 3.0 & 1.28 & $0.00-6.38$ & 2.56 & $0.00-7.76$ & 0.00 \\
\hline Milk and dairy products & 1.5 to 2.5 & 0.16 & $0.00-3.94$ & 1.50 & $0.00-8.46$ & 0.00 \\
\hline Nuts & 0.5 to 1.5 & 0.00 & $0.00-0.00$ & 0.00 & $0.00-6.80$ & 0.31 \\
\hline Vegetable oils & 2.0 to 3.0 & 2.25 & $0.46-10.77$ & 1.72 & $0.20-24.67$ & 0.90 \\
\hline
\end{tabular}

Note: "Whole grains and bread, tubers, and roots; ${ }^{* *}$ Tests for analyzing servings before $\mathrm{x}$ after intervention: Wilcoxon for nonparametric variables and Student's $t$ test for parametric variables.

Min: Minimum; Max: Maximum.

classified as moderation components, especially sugars and sweets, refined grains, beef, and pork. The intake of these items on weekdays and weekends exceeded the reference values.

\section{I SCUSSIO N}

Health education seems to benefit when information is disseminated through different channels ${ }^{14}$. The food and nutrition education program conducted at the institution included strategies of nutritional counseling in different formats and channels, increasing group involvement and participation. The use of games, group dynamics, cooking workshops, and lectures was appropriate for the educational content, encouraged the students to reflect about and discuss the subject, and motivated all participants. These activities allowed a less formal interaction between the students and the technical team, encouraging the students to express their thoughts about the discussion themes more spontaneously.

Similar results using non-conventional teaching techniques, such as cooking workshops, as a nutrition education tool have been described by Toassa et al. ${ }^{14}$, Marin et al. ${ }^{15}$, and Pereira \& Sarmento ${ }^{16}$, who aimed to promote adolescent health using educational practices. Thus, the use of active methodology techniques in adolescent education not only has good results, but also is recognized as the necessary measure for reducing food and nutrition education dropout rates.

The study food and nutrition education program improved the adolescents' nutritional profile significantly, even though some students still had inappropriate BMI after the intervention. The prevalence of overweight and obesity in this study was $24.2 \%$ before and after the intervention, which is higher than the prevalences reported by a nationally representative survey conducted in 2008-2009 with adolescents aged 16 to 17 years (17.5\%) and adolescents aged 18 to 19 years (19.2\%). These results deserve attention, since overweight and obese adolescents tend to maintain this nutritional status throughout adulthood, increasing their risk of NCD ${ }^{17}$. Changing the weight of most of these adolescents significantly, especially when excessive, requires an ongoing, long-term, and multidisciplinary 
intervention ${ }^{18}$. Moreover, the obstacles and limiting factors in the treatment of excess weight also have to be considered, such as genetic factors, which influence individuals' susceptibility to obesity. This susceptibility manifests in favorable environments, where lifestyle also plays an important role. On the other hand, ideological, cultural, and emotional factors influence the formation of adolescents' food habits and their perception of hunger, appetite, and satiety. Most adolescents have some typical food behaviors and habits, such as skipping breakfast, high intake of energy-dense foods, and high vulnerability to the pressure exerted by the media and society for the attainment of often unattainable appearance or underweight, possibly increasing their odds of developing eating disorders ${ }^{19}$.

Studies that provided nutrition education to children and adolescents as one of the intervention strategies reported an increase in their subjects' nutritional knowledge and healthy food attitudes $^{19,20}$. These data corroborate the present study, which observed a higher frequency of healthy food attitudes and practices, a reduction in the percentage of students who added salt to food or sugar to juice, better nutrition knowledge, and better understanding of food labels, evidencing the effectiveness of the study food and nutrition education program.

Although some students stopped adding sugar to juice, the IQD-GAD revealed that this population had high intake of sugars and sweets. This finding indicates the need of informing this group about the importance of reducing sugar intake since sugar increases energy intake significantly, contributing to weight gain and to the development of diseases associated with the metabolic syndrome ${ }^{21}$. In this context, sugar intake currently recommended by the $\mathrm{WHO}^{22}$, including the intake of glucose, sucrose, and fructose, decreased from 10 to $5 \%$ of the total daily energy intake, which affects the intake of beverages, doughs, and even the sugar naturally present in juice and fruits.
Foreign studies found that children's and adolescents' knowledge on nutrition increased after exposure to food and nutrition education programs at school. The researchers reported a significant impact on students' food knowledge and eating behavior, emphasizing lower intake of high-sodium and high-sugar foods 23,24 .

Although sodium intake was not assessed, its addition to food reported by the adolescents is in agreement with one of the premises of the new Brazilian Food Guide 2 , which is the use of sodium with moderation based on studies that relate high sodium intake with increased risk of cardiovascular diseases.

Knowledge on adolescents' diet quality provides information to substantiate the creation of nutritional health indicators that allow early interventions and monitoring the main dietary factors ${ }^{25}$. Since the intervention improved the dietary pattern classification and diet quality on weekdays and weekends, the study food and nutrition education program reached its objectives.

Studies that assess the diet quality of adolescents using the IQD-GAD were not found in the literature. Most studies of adolescents assess diet quality with traditional nutritional tools, such as the three-day food record and the food frequency questionnaire, and few studies use other indices. The present study was the first to use the IQD-GAD on adolescents. The intervention impacted most the food groups classified as adequacy components, which promote health when consumed adequately.

Gabriel et al. ${ }^{26}$ also reported a significant increase in fruit intake by students after an intervention. However, like other studies ${ }^{27,28}$ that used the IQD to estimate adolescents' fruit intake, fruit intake was below the recommended intake, except in the study by Wendpap et al. ${ }^{29}$.

Higher vegetable intake was also reported by Jaime et al. ${ }^{30}$ in a study of low-income Brazilian families after an intervention, and by Baranowski et al. ${ }^{31}$ in a study of adolescents after exposure to 
food and nutrition education actions. However, in most cases vegetable intake was still short of the recommended intake, despite the higher intake promoted by interventions ${ }^{32,33}$.

Studies conducted in the United States, England, and Australia with children and adolescents report that food and nutrition education actions at school increase students' intake of fruits and vegetables and their knowledge on these subjects. These effects seem even greater when schools have gardens and/or include these foods in their meals ${ }^{34-36}$.

As the students increased their legume, milk, and dairy product intakes, they reached the recommended intakes for these foods, exceeding the intakes reported by other studies ${ }^{37,38}$.

The provision of healthy meals during meal breaks aims to supplement the students' diets, improving their nutritional status and learning ability, and forming good food habits ${ }^{1}$. In this context, another important aspect was the supply of fruits, vegetables, and legumes in the main meal (lunch), and milk in the smaller meals (breakfast and afternoon snack) served by the institution to the students during the food and nutrition education program. In the long run, this practice may have contributed to the students' higher intake of these foods.

The intervention actions did not affect the intake of most food groups classified as moderation components, especially sugars, sweets, and refined grains, reinforcing the need to review program actions that cover this subject, making them more effective.

Also deserving of attention are the contradictory messages that reach adolescents. Although education programs and healthpromotion campaigns disseminate messages that encourage healthy food habits, processed and ultra-processed foods, most of which are high in sugars, fats, and refined grains, occupy an increasingly higher share of the food market. These foods are inexpensive, guaranteed to be practical, and lead to taste development and dependence, which increasingly induces their preference. They reach young and low-income individuals, and strongly influence their food choices $^{18,27,38}$. These results reinforce the importance of dieticians' influence in spaces frequented by adolescents, as well as of public policies on the marketing of these products.

A limiting factor of this study is the fact that little is known about the families' habits and culture, which proved to be a barrier to an effective intervention on inappropriate long-term food practices, which appears to be the case of excessive intake of high-sugar and high-fat foods. Not assessing the nutritional composition and value of the meals offered by the institution was also a limiting factor, which can be a determinant for a change in habit.

As discussed, there are many reports in the literature of school food and nutrition education programs, but long-term studies conducted in nonprofit institutions involving adolescents are rare. Even scarcer is the number of studies systematizing the methods and results of nationwide school experiences.

Although the reported intervention has achieved a positive result, the maintenance of healthy food practices requires the provision of long-term programs and not just isolated actions. food and nutrition education is a long process. Better results require continuity, permanence, and improvement, like any educational action, making food and nutrition education a challenge for health teachers and professionals $\mathrm{s}^{39}$.

\section{CONCLUSION}

The study food and nutrition education strategy effectively promoted better nutritional status and dietary patterns in the participants, making it a viable and inexpensive method to prevent diseases, and improve health and quality of life.

The increase in diet classification and quality indicated that the food and nutrition 
education program improved the eating pattern of the youth, having the greatest impact on the intake of most food groups classified as adequacy components, which benefit health when consumed adequately.

The Diet Quality Index associated with the Digital Food Guide instrument enabled the assessment of changes in the food intake of adolescents submitted to a food and nutrition education program, constituting an important tool for guiding future nutrition intervention actions in this population.

\section{CONTRIBUTORS}

J BALDASSO collected, analyzed, interpreted the data and drafted and wrote the article. A GALANTE supervised the study and revised the article. A DE PIANO GANEN supervised the study, drafted, wrote and revised the article.

\section{REFERE N CES}

1. Brasil. Ministério da Saúde. Política Nacional de Alimentação e Nutrição (PNAN). Série B. Textos Básicos de Saúde. Brasília: Ministério da Saúde; 2012.

2. Brasil. Ministério da Saúde. Secretaria de Atenção Básica. Guia Alimentar da População Brasileira. Brasília: Ministério da Saúde; 2014.

3. Horta PM, Ferreira AD, Santos LC. Impacto de um programa de educação nutricional em adolescentes estudantes da rede pública. Rev APS. 2012; 15(2):185-91.

4. Oliveira AC, Haddad S. As organizações da sociedade civil e as ONGs de educação. Cad Pesqui. 2001; (112):61-83.

5. Schmitz BAS, Recine E, Cardoso GT, Silva JRM, Amorim NFA, Bernardon R, et al. A escola promovendo hábitos alimentares saudáveis: uma proposta metodológica de capacitação para educadores e donos de cantina escolar. Cad Saúde Pública. 2008; 24(2):312-22.

6. Belik W, Chaim NA. O Programa Nacional de Alimentação Escolar e a Gestão municipal: eficiência administrativa, controle e social, desenvolvimento local. Rev Nutr. 2009; 22(5):595-607. http://dx.doi. org/10.1590/S1415-52732009000500001

7. Brasil. Ministério da Saúde. Sistema de Vigilância alimentar e nutricional - Sisvan: orientações básicas para a coleta e processamento, análise de dados e informação em serviços de saúde. Brasília: Ministério da Saúde; 2011.

8. World Health Organization. WHO Child Growth Standards: Methods and development. Length/ height-for-age, weight-for-age, weight-for-length, weight-for-height and body mass index-for-age. Geneva: WHO; 2007.

9. Caivano S, Domene SMA. Diet quality index for healthy food choices. Rev Nutr. 2013; 26(6):693-9. http://dx.doi.org/10.1590/S1415-527320130006 00008

10. Universidade Estadual de Campinas. Núcleo de Estudos e Pesquisas em Alimentação. Tabela Brasileira de Composição de Alimentos - TACO. $2^{\mathrm{a}}$ ed. Campinas: Unicamp; 2006.

11. United States Departament of Agriculture. Nutrient Data Laboratory. Beltsville (MD): USDA; 2014 [cited 2014 Aug 18]. Available from: http://ndb.nal.usda. gov

12. Institute of Medicine. Dietary reference intakes: The essential guide to nutrient requirements. Washington (DC): National Academy Press; 2006.

13. Institute of Medicine. Dietary reference intakes: Calcium, phosphorus, magnesium, vitamin D and fluoride. Washington (DC): National Academy Press; 2010.

14. Toassa EC, Leal GVS, Wen CL, Philippi ST. Atividades lúdicas na orientação nutricional de adolescentes do Projeto Jovem Doutor. Nutrire Rev Soc Bras Aliment Nutr. 2010; 35(3):17-27.

15. Marin T, Berton P, Santo LKR. E. Educação nutricional e alimentar: por uma correta formação dos hábitos alimentares. Rev F@pciência. 2009; 3(7):72-8.

16. Pereira MN, Sarmento CTM. Oficina de culinária: uma ferramenta da educação nutricional aplicada na escola. Universitas Ciênc Saúde. 2012; 10(2):87-94.

17. Instituto Brasileiro de Geografia e Estatística. Pesquisa de Orçamentos Familiares - POF, 2008-2009: antropometria e estado nutricional de crianças, adolescentes e adultos no Brasil. Rio de Janeiro: IBGE; 2010.

18. Dobbs R, Sawers C, Thompson F, Manyika J, Woetzel J, Child P, et al. Overcoming obesity: An initial economic analysis. New York: McKinsey \& Company; 2014.

19. Muller MJ, Mast M, Asbeck I, Langnase K, Grund A. Preventions of obesity: It is possible? Obes Rev. 2001; 2(1):15-28.

20. Pérez-Rodrigo C, Aranceta J. School-based nutrition education: Lessons learned and new perspectives. Pub Health Nutr. 2001; 4(1):131-9. 
21. Lustig RH, Schmidt LA, Brindis CD. The toxic truth about sugar. Nature. 2012; 482:27-29 http://dx. doi.org/10.1038/482027a

22. World Health Organization. Guideline: Sugars intake for adults and children. Geneva: WHO; 2015.

23. Francis $M$, Nichols SS, Dalrymple N. The effects of a school-based intervention programme on dietary intakes and physical activity among primary-school children in Trinidad and Tobago. Public Health Nutr. 2010; 13(5):738-47.

24. Shah P, Misra A, Gupta N, Hazra DK, Gupta R, Seth $\mathrm{P}$, et al. Improvement in nutrition-related knowledge and behavior of urban Asian Indian school children: Findigs from the 'Medical education for children/ adolescents for realistic prevention of obesity and diabetes and for healthy aGeing' (MARG) intervention study. Br J Nutr. 2010; 104(3):427-36.

25. Fisberg MR, Slater B, Barros RR, Lima FD, Cesar CLG, Carandina $L$, et al. Índice de Qualidade da Dieta: avaliação da adaptação e aplicabilidade. Rev Nutr. 2004; 17(3):301-18. http://dx.doi.org/10.1590/S 1415-52732004000300003

26. Gabriel CG, Santos MV, Vasconcelos FAG. Avaliação de um programa para promoção de hábitos alimentares em escolares de Florianópolis, Santa Catarina, Brasil. Rev Bra Saúde Mater Infant. 2008; 8(3):299-308

27. Monteiro CA, Cannon G. The Impact of Transnational "Big Food" Companies on the South: A View from Brazil. PLoS Med. 2012; 9(7):e1001252. http://dx. doi.org/10.1371/journal.pmed.1001252

28. Currie C, Gabhainn SN, Godeau E, Roberts C, Smith $R$, Currie $D$, et al. Inequalities in young people's health. HBSC International Report from the 2005/ 2006 survey. Copenhagen: WHO Regional Office for Europe; 2008.

29. Wendpap LL, Ferreira MG, Rodrigues PRM, Pereira EA, Loureiro AS, Goncalves S, et al. Qualidade da dieta de adolescentes e fatores associados. Cad Saúde Pública. 2014; 30(1):97-106.

30. Jaime PC, Machado FMS, Westphal MF, Monteiro AC. Educação nutricional e consumo de frutas e hortaliças: ensaio comunitário controlado. Rev Saúde Pública. 2007; 41(1):1-4.

31. Baranowski T, Davis M, Resnicow K, Baranowski J, Doyle C, Lin LS, et al. Gimme 5 fruit, juice, and vegetables for fun and health: Outcome evaluation.
Health Educ Behav. 2000; 27(1):96-111. http:// dx.doi.org/10.1177/109019810002700109

32. Baranowski T, Baranowski J, Cullen KW, Marsh T, Islam N, Zakeri I, et al. Squire's Quest! Dietary outcome evaluation of a multimedia game. Am J Prev Med. 2003; 24(1):52-61.

33. He M, Beynon C, Sangster BM, St Onge R, Stewart $S$, Khoshaba $L$, et al. Impact evaluation of the Northern fruit and vegetable pilot programme: A cluster-randomised controlled trial. Public Health Nutr. 2009; 12(11):2199-208.

34. Parmer SM, Salisbury-Glennon J, Shannon D, Struempler B. School gardens: An experimental learning approach for a nutrition education program to increase fruit and vegetable knowledge, preference, and consumption among second-grade students. J Nutr Education Behav. 2009; 41(3):212-7.

35. Morgan PJ, Warren JM, Lubans DR, Saunders KL, Quick GI, Collins CE. The impact of nutrition education with and without a school garden on knowledge, vegetable intake and preferences and quality of school life among primary-school students. Public Health Nutr. 2010; 13(11):1391-940.

36. Ransley JK, Taylor EF, Radwan Y, Kitchen, MS, Greenwood DC, Cade JE. Does nutrition education in primary schools make a difference to children's fruit and vegetable consumption? Public Health Nutr. 2010; 13(11):1898-904.

37. Godoy FC, Andrade SC, Morimoto JM, Carandina L, Goldbaum M, Barros MBA, et al. Índice de Qualidade da Dieta de adolescentes residentes no distrito do Butantã, município de São Paulo, Brasil. Rev Nutr. 2006; 19(6):663-671. http://dx.doi.org/10.15 90/S1415-52732006000600003

38. Moodie R, Stuckler D, Monteiro C, Sheron N, Neal $B$, Thamarangsi $T$, et al. Profits and pandemics: Prevention of harmful effects of tobacco, alcohol, and ultra-processed food and drink industries. Lancet. 2013; 381(9867):670-9.

39. Vargas ICS, Schieri R, Sandre-Pereira G, Veiga GV. Avaliação de programa de obesidade em adolescentes de escolas públicas. Rev Saúde Pública. 2011; 45(1):59-68.
Received: May 21, 2015 Final version: July 14, 2015 Approved: September 21, 2015 
